\title{
A survey of demand response adoption in retail stores DR control preferences, stakeholder engagement, and cross- national differences
}

\author{
Zheng $\mathrm{Ma}^{1 *} \mathbb{B}$, Kati Kuusinen ${ }^{2}$ and Mikkel Baun Kjærgaard ${ }^{3}$
}

\footnotetext{
* Correspondence: zma@mmmi.sdu. dk

${ }^{1}$ SDU Center for Health Informatics and Technology, University of Southern Denmark, Odense, Denmark

Full list of author information is available at the end of the article
}

\begin{abstract}
Retail stores can participate in demand response programs with the possibility of load shifting and building automation systems. Demand response activities in retail stores are influenced by various factors, such as business operations, company goals and policies, etc. Meanwhile, the demand response participation can potentially disrupt occupants' (e.g. customers and employees) lifestyles, thermal comfort and health as well as potentially increase cost or energy consumption. Therefore, stakeholders' acceptance and behaviors are crucial to the retail stores' success of demand participation. Therefore, this paper conducted a questionnaire with retail stores to investigate retail stores' preferences of demand response programs and stakeholders' engagement. The questionnaire is designed and collected with energy/ store managers (who are responsible for energy in stores) in Denmark $(N=51)$ and the Philippines $(N=36)$. The result shows that: 1$)$ retail stores are more willing to participate in the implicit demand response by manual energy control compared to the utility control or building automation. Meanwhile, retail stores have significant concerns about business activities and indoor lighting compared to other aspects; 2) the statistically significant influential factors for retail stores to participate in the demand response are related to whether demand response participation matches company goals, influences business operation, and whether retail stores are lack of related knowledge; 3 ) retail stores believe that employees and customers should be informed about the demand response activities but not involved in; 4) there are significant differences regarding energy control preferences and concerns between retail stores in Denmark and the Philippines, but no significant difference regarding employees' and customers' engagement.
\end{abstract}

Keywords: Energy flexibility, Retail stores, Demand response preference, Employee engagement, Customer engagement, Utility collaboration

\section{Introduction}

Smart grid is one of the most effective and economical solutions on the path to a future energy system (Energinet.dk, 2010). Smart grid functionality depends on the collaboration and integration of different stakeholders, adoption of new technologies, regulations and business models (Samad \& Kiliccote, n.d.; Heiskanen \& Matschoss, 2011; Gungor et al., 2011; Vukojevic \& Milošević, 2010). The existing

(c) The Author(s). 2019 Open Access This article is distributed under the terms of the Creative Commons Attribution 4.0 International License (http://creativecommons.org/licenses/by/4.0/), which permits unrestricted use, distribution, and reproduction in any medium, provided you give appropriate credit to the original author(s) and the source, provide a link to the Creative Commons license, and indicate if changes were made. 
literature indicates the importance of consumer engagement in Demand Response (DR) management that can contribute to the stability and agility of the smart grid (Ma et al., 2018a; European Environment Agency (EEA), 2013).

Energy flexibility provided by consumers depends on the types of consumers, e.g. industrial, commercial and residential consumers (Samad \& Kiliccote, n.d.). For instance, some industrial consumers, e.g. refrigeration companies/ cold stores, have especially high load shift potential with the duration of several hours, and there are several ways to make electricity from refrigerators/ freezers more flexible (Energianalyse, 2011). However, the majority of the industrial processes are more resistant to provide energy flexibility compared to commercial activities due to continuous production. DR for commercial consumers is popularly discussed due to 1) about one-third of the overall commercial buildings are equipped with Building Automation Systems (BAS) in many developed countries, 2) BAS already integrates the HVAC (Heating, Ventilation, and Air Conditioning) control systems that can manipulate the control variables needed for providing regulation services, 3) a large fraction of commercial buildings are equipped with fast-responding Variable Frequency Drives (VFDs) (Hao et al., 2012). However, some commercial consumers are more reluctant to participate in DR due to the influences on their business routines and profits (Yang \& Wang, 2016). For instance, hotels operate $24 / 7$ and are in general reluctant to shift their usage of power due to consideration of their profits or occupants' comfort.

DR success is related to various aspects, e.g. regulation, consumers' motivation, electricity suppliers' support, and also depends on the collaboration of all smart grid actors (Energinet.dk, 2011). The flexibility activation can require the establishment of agreements between different actors. Following agreements may be negotiated between aggregators and prosumers, such as: security of supply on time from prosumers' side, comfort requirements from prosumers' side, framework for billing, and aggregator's active marketing role to engage consumers in the delivery of flexibility products (to DSOs (Distribution System Operators)/ grid companies, TSOs (Transmission System Operators) etc.) (Energinet.dk, 2012). For instance, in retail stores, several stakeholders discussed in literature should be involved in DR, including store managers, employees, and shoppers.

Although the importance of consumer engagement is discussed (e.g. (Ma et al., 2018a; Ma, 2016)), few studies have investigated the stakeholders' roles and engagement in DR. Stakeholder acceptance and behavior are crucial to the success of DR participation. Introducing demand response has potentials to disrupt occupant lifestyles, thermal comfort and health as well as potentially increasing cost or energy consumption. Stakeholder acceptance and behavior may also be a barrier, but this can be reduced, or overcome entirely if related stakeholders are informed and support any flexibility measure that is introduced. The technic solutions for participating demand response may not be feasible as the consequences that involved stakeholders may not accept the solutions. Stakeholders' acceptance, therefore, is an important input to the DR participation strategies.

This paper selects retail stores to investigate the stakeholders' engagement in DR programs. The retail store is one type of commercial buildings selling a variety of products, owned or operated by the retailers (Ma et al., 2017a). Retail stores are large commercial energy consumers, as they have round-the-clock business operations (Robert et al., n.d.). Energy consumption of retail stores depends on the 
nature of the business, store format, products, shopping activities of customers and store equipment (Kolokotroni et al., 2015). There are many ways for energy control in retail stores. For instance, improving lighting system design and incorporate daylight-saving reduces energy costs (Hayter, n.d.). Retail stores can potentially provide various energy flexibilities, such as the flexible operation of refrigeration in supermarkets.

Store managers in retail stores (or called 'energy managers' in large retail stores) take an important role in DR participation. Store managers are assigned in the corporate department of large retail stores with responsible for developing effective energy management plans, evaluation and installation of energy technologies, and negotiating with utility partners regarding electricity prices (JRC Science Hub, 2015; Carr, 2015). They are responsible for supervising stores' security, maintenance and repair in accordance with stores' environmental and safety standards. On the other hand, store managers are responsible for energy management practices in retail stores in the coordination of retail store operation (Robert et al., n.d.; Ochieng et al., 2014). Other stakeholders discussed in the literature that are involved in the energy-related activities in retail stores are: shop-floor-staffs, customers and utilities. However, they are passively involved in decision making and planning. Therefore, store managers are the main responsible for retail stores' DR program participation and stakeholders' involvement.

This paper presents the results of a survey study conducted in Denmark and the Philippines to investigate the research question: what factors significantly influence retail stores' DR participation? And whether there are cultural differences? Two countries, Denmark and the Philippines, are selected in the paper for a comparative study to fill the literature gap in cross-national energy flexibility. The literature on cross-national comparison in energy mainly focus on energy consumption (e.g. (Mehrara, 2007)), renewable energy resources (e.g. (Huber et al., 2014)) and building energy use and regulations (e.g. (Iwaro \& Mwasha, 2010)). So far, there is no cross-national study on energy flexibility of retail stores. Therefore, to understand the cultural impact, this study chooses Denmark and the Philippines to investigate the cross-cultural similarities and differences in retail stores' DR adoption and participation. Although there are many differences between Denmark and the Philippines, e.g. climate, regulation, economics and culture, energy technology exporting from Denmark to the Philippines is one of the top interests for Danish companies partly due to the energy investment agreement and partnership between EU and the Philippines (Council of the European Union, 2011). The investigation of these differences and similarities between the two countries can help to further understand the business opportunities for smart energy solutions.

The questionnaire is designed and collected with energy/stores managers of retail stores in Denmark $(N=51)$ and the Philippines $(N=36)$. Depends on the size of the retail stores, some large stores have energy managers to be in charge of energy-related matters, and usually, store managers in smaller retail stores are responsible for energy consumption and activities. The questionnaire contains three aspects (DR control preferences, motivation, and barriers for DR participation, and stakeholder engagement) to investigate the DR adoption in retail stores. These three aspects are discussed and stated in literature as important factors for retail stores' energy-related activity participation. 
This paper firstly discusses the related literature on energy flexibility in retail stores, and then introduces the adopted methodology. The section of results and discussion presents the results of the surveyed data analysis, each sub-section corresponds to one hypothesis $(\mathrm{H} 1-\mathrm{H} 4)$ and the $\mathrm{H} 5$ is presented in other hypotheses. Finally, an object-oriented approach for retail stores preparing their readiness for DR participation is proposed and discussed.

\section{Research background}

Energy management activities in retail stores vary according to store conditions, e.g. store size, store type (Robert et al., n.d.). Other factors, such as energy plans, responsible staffs, existing/new buildings, and store activities, also affect the energy adoption in retail stores. Meanwhile, energy price, consumption, climate, and infrastructures vary according to regions or locations. Beside store conditions, DR control options, store managers' preferences and concerns, and stakeholders' involvement influence the success of DR implementation in retail stores:

\section{DR control options and retail stores' concerns}

There are two types of demand response (DR) programs: explicit and implicit demand response. The two types of DR programs are activated at different times and serve different purposes in markets (Ma et al., 2017b). Implicit DR (sometimes called pricebased DR) assumes that electricity consumers may alter their electricity consumption due to a price signal that is provided at a different time (Mandatova \& Lorenz, 2013). Meanwhile, explicit DR (also called incentive-based DR program) is divided into traditional-based (e.g. direct load control, interruptible pricing) and market-based (e.g. emergency demand response programs, capacity market programs, demand bidding programs, and ancillary services market programs) (Sebastian \& Margaret, 2016). In explicit DR, load requirements (size of energy consumption) need to comply to participate in DR programs (Lamprinos et al., 2016). Therefore, there are different requirements for consumers to participate in implicit and explicit DR, and consumers receive benefits via different business models.

However, the acceptance and adoption of the DR options not only depend on the monetary benefits of DR programs but also the energy use and consumers' behaviors. The retail stores' energy consumption focus on various areas including indoor and outdoor lightings, heating, air-conditioning, building maintenance, planning/ operations, refrigeration and lobbying (Mills, 1984). The indoor air quality (IAQ) is one of the important components in energy management for retail stores due to the building regulation and customers' satisfaction (Zaatari et al., 2016). Meanwhile, the energy plan and activities in the retail stores need to consider the retail store image, cost, competition, regulations, internal concerns, and customer satisfaction. The retail store image is an essential element as it influences customers' shopping decisions.

The DR activities in retail stores are influenced by the availability and readiness of energy flexibility technologies. The technologies provide the resources of energy flexibility in retail stores. Lightings, refrigerators, and ventilation are common technologies available in stores. Lighting is the most important technology considered in buildings. Effective lighting can increase shoppers' satisfaction and encourage them to spend more 
time in the stores (Gerdeman, 2007). Meanwhile, Store lighting is a high energy expenditure in retail stores. There is a need for lighting for refrigerators, walk-in coolers, sales areas, and garage/parking. The energy consumption can be reduced by as much as $50 \%$ with the simple application of energy efficiency technologies (Energianalyse, 2015). Refrigeration is used to store perishable products in the stores sharing up to $47 \%$ of energy consumption in retail store (Connell et al., 2014). There are several technologies that can improve the energy efficiency of the refrigeration in supermarkets, such as anti-sweat heater controls for refrigerated cases, strip curtains for walkin coolers and freezers to help mitigate cold air spill. Ventilation provides comfort to building occupants (e.g. staffs and customers) and increase stores' productivity (Zaatari et al., 2016). Ventilation rates are mandated by regulations and standards, such as indoor air quality, health requirements, and climate. The ventilation control technologies and strategies (e.g. HVAC control systems) not only can provide energy saving but also the energy flexibility (Carr, 2015; Leal, 2000).

Accordingly, we offer the following hypothesis:

H1: Retail stores have concerns toward different DR control options

\section{Influential factors for retail stores' DR program participation}

Majority of retail stores have been aware of the importance of energy-saving and energy efficiency. Literature indicates that the influential factors that might impact retail stores' acceptance of demand response can be divided into financial technological, business, legal and environmental aspects.

The demand response enhances the energy efficiency of retail stores, utilities, and grid operators. Recent research shows that demand response is considered as a secondary revenue stream for a supermarket chain as it lowers electricity cost (Connell et al., 2014) and lowers the wholesale energy market prices (Jianli et al., 2014). For instance, the demand response in the refrigeration system allows the adjustment of the demand for electricity (Connell et al., 2014). Moreover, the energy crisis is a driver for the demand response implementation in retail stores. Recent research shows that that retail stores agree that there is an energy crisis in the US and it has affected their store operation (Mills, 1984). The increasing energy cost affects product pricing in grocery stores and food supermarkets (Ochieng et al., 2014; Mills, 1984). Although the electricity cost is only $1 \%$ of the total supermarket operating cost, retail stores are interested in any financial incentive that can generate profits (Connell et al., 2014). It especially drives the stores that consume a large amount of electricity (e.g. grocery, food supermarket) to consider energy flexibility.

Retail stores comply with the political directives when it is implemented through the retail organizations or association (Mills, 1984). Retailers adopt energy-efficient technologies and flexibility resources (e.g. photovoltaics or energy storage) mainly due to the energy legislation and building regulations. For instance, the food supermarkets apply efficient energy technologies because of the rising energy cost and campaigns of Non-Governmental Organization (NGO) to reduce Greenhouse gas (GHG) emissions (Ochieng et al., 2014). However, not all supermarkets are convinced to adopt demand response programs (Ochieng et al., 2014). Tassou et al. (Tassou et al., 2010) research shows that retail stores receive pressure to practice energy management because of the energy legislation implemented by the government. The policymakers need to increase 
their effort in reaching out to the retail industries by building a strong communication channel and utilizing the energy information (Mills, 1984). For instance, in the US, the Department of Energy (DOE) provides a web-portal as an information tool to build a strong collaboration with their energy partners (e.g. retail stores) (Carr, 2015).

Retail stores are a highly competitive customer-driven market, and the first priority of retail stores is developing effective strategies to attract different types of customers (e.g. new or existing customers, and green-conscious consumers) (Ochieng et al., 2014). Research shows that customers' behaviors and shopping decisions can be influenced by the retail stores' reputation and strategies. The business strategies include factors of demands, beliefs and customer values. Corporate Social Responsibility (CSR) is an effective strategy to create sustainable competitive advantage and develop a good company image, trust with the local communities and customers (Ochieng et al., 2014). A good CSR strategy can catch customers' attention, e.g. creating customers' awareness of the utilization of efficient energy technologies in retail stores and the benefits of environmental-friendly and health-related smart energy. Another example of good CSR practice is providing an environmentally friendly condition to the users without a high amount of energy (Kolokotroni et al., 2015). In general, good CSR practices are common strategies for energy flexibility in the retail stores with the collaboration between retailers and customers/local communities, especially cooperatives' action towards climate targets become national and international obligation.

Accordingly, we offer the following hypothesis:

H2: Retail stores' DR program participation is related to various influential factors

\section{Stakeholders' involvement in the retail stores' demand response activities}

There are internal and external stakeholders potentially involved in the demand response for retail stores, and they participate in different roles. The literature identifies that the main internal stakeholders in the stores are building/store owners and managers, store managers, and shop-floor staffs.

Building owners are the owners of buildings. They collaborate with the design teams for the designing of the energy-efficient and flexible buildings with related technologies. Usually, the building owners are responsible for implementing the energy development program in retail stores (Robert et al., n.d.). Building/store managers collaborate with governments and other stakeholders regarding the monetary energy efficiency incentive programs (Carr, 2015). They are responsible for supervising the buildings' security, maintenance and repair in accordance with buildings' environmental and safety standards. On the other hand, store managers (Ochieng et al., 2014) are responsible for energy management practices in retail stores and manage the retail store operation (Robert et al., n.d.). Energy management specialists or retail store managers are assigned in the corporate department of large retail stores with the responsibility of developing effective energy management plans, evaluation and installation of energy management technologies, and negotiating with the utility partners regarding the electricity prices (Energinet.dk, 2010).

Shop-floor-staffs work under the supervision of the store managers. They are responsible for the maintenance of the stores' daily operation including the energy management practice in the stores (Robert et al., n.d.). There might be multiple-goal conflicts 
affect shop-floor staffs' involvement in the demand response activities in stores (Christina et al., 2014). Some of the demand response activities affect shop-floor staffs rather than customers. For instance, the customers might not be aware of the indoor temperature changes in the supermarkets, but the temperature changes would significantly influence the shop-floor staffs due to the long working duration in the supermarkets. A survey shows that shop-floor staffs do not actively participate in the energy efficiency programs of the retail stores unless the energy-related programs are considered as a part of the job functions or with incentives (e.g. credit, or bonus) (Christina et al., 2014).

Several external stakeholders might influence retail stores' energy management strategies. For instance, utility companies supply energy to retail stores, and concern profit from generating and saving energy (Hutchinson, 2012). The partnership between the retailers and utility companies brings energy flexibility products/solutions closer to the retailers. For example, in the US, utility companies and retailers work together and create the "build your own energy" incentive solution to respond to the government's energy development program. This energy incentive program serves as a tool to utilize efficient energy technologies for new construction and existing retail store buildings (Carr, 2015). However, in general, there is still lack of incentive of energy flexibility participation from the utilities or governments, either some utility incentives are not applicable to retail stores, nor some incentives are classified on certain groups (e.g. motor replacement or one-for-one equipment change out incentives) (Carr, 2015).

Local communities refer to a group of people or individuals in the society and involve in different community programs (e.g. incentive energy efficiency program) (Carr, 2015). Retail store customers are involved in shopping and buying activities in retail stores. The "energy retail stores customers" are classified as environmentally conscious, cost-conscious and technology-conscious customers (Hutchinson, 2012). Literature shows that the demand response activities in retail stores do not significantly influence customers' shopping experience. An experiment in a large British supermarket shows that the customers do not realize the changes in the indoor temperature during the experiment. Meanwhile, the energy control systems provide the energy flexibility potentials with customers' interaction (Ochieng et al., 2014).

The literature shows that some external stakeholders indirectly influence energy performance and plan in retail stores. For instance, third-party private operators collaborate with retailers in the renovation of building design, energy development, and energy production. Third-party private operators consist of remodeling specialists, energy development consultants, energy engineers, and energy researchers. Remodeling specialists (Vukojevic \& Milošević, 2010) involve in the building renovation or redesign. The development consultants are independent contractors who are hired by an organization to develop effective energy management plans. On the other hand, energy engineers (Hutchinson, 2012) involve in energy production and are also involved in energy equipment design and selection. Meanwhile, governments or regulators are involved in planning and developing energy policies (Samad \& Kiliccote, n.d.), regulate energy rules that shape the future energy systems (e.g. Department of Energy) (Carr, 2015).

Accordingly, we offer the following hypothesis:

H3: Retail stores have preferences for employees' participation in DR activities

H4: Retail stores have preferences of customers' participation in DR activities 


\section{Cultural impact on the building energy flexibility}

The smart grid becomes a priority of many countries due to various national reasons like growing population size or climate change. The reasons and solutions for the energy flexibility across countries vary due to the maturity of the energy system and the renewable energy resources potentials. Other factors might also influence national energy flexibility development, such as economic and climate situations. The factors can be divided into five aspects (Ma et al., 2019): climate and environment, societal culture and demographics, technology (Infrastructure, technological skills, relevant technology readiness), economy and finance, policy and regulation. Societal culture strongly influences the adoption of energy solutions (Ma et al., 2019; Ma et al., 2018b).

Taking Denmark and the Philippines as an example, both countries have high electricity price. Denmark has the highest electricity price in Europe (Eurostat, 2018), and there is little motivation for buildings in Denmark to provide energy flexibility due to the high percentage of tax and grid tariffs in the electricity price (Danish Energy Association, 2013). The Philippines has one of the most expensive electricity prices in Asia (Department of Energy, 2016) because the country is dependent on imported fuel and the government does not provide electricity subsidy. In the Philippines, private distribution utilities decide the electricity retail price according to locations and types of consumers. Comparatively, there is an unbundling electricity market in Denmark.

Furthermore, the resources of energy flexibility provided by buildings in Denmark and the Philippines are different. For instance, the majority of residential buildings are not equipped with the air conditioning in Denmark but district heating. Comparatively, the air conditioning is compulsory in buildings (if the building owners can afford) due to the climate, but no heating system in the Philippines. In the Philippines, the solar panels are commonly installed in buildings. However, the electricity produced from the solar panels is only for self-usage and is not allowed to sell back to the grid. In Denmark, buildings with solar panels are allowed to sell the electricity produced from the solar panels to sell back to the grid. Therefore, the incentives for buildings to provide energy flexibly between Denmark and the Philippines are different.

Meanwhile, buildings in the Philippines have to provide energy flexibility by tolerancing frequent electricity blackout. With a population of more than 100 million people, there are 16 million who are not connected to the electricity grid in the Philippines (Gonzales, 2013). Comparatively, there would be only 7 min of power shortage in Eastern Denmark, in 2018 (EnergiNet, 2017).

Besides many differences of the energy systems between Denmark and the Philippines, there are similarities that enable the energy solution exporting between these two countries, e.g. unbounding market structure (both have wholesale and retail market), high electricity price, the political focus on renewable energy resources, etc. (Ma et al., 2016a; Ma et al., 2016b; Zheng et al., 2016).

Accordingly, we offer the following hypothesis:

H5: National cultures have an effect on retail stores' DR adoption and participationThe conceptual model that illustrates retail stores' DR adoption and participation shown in Fig. 1. 


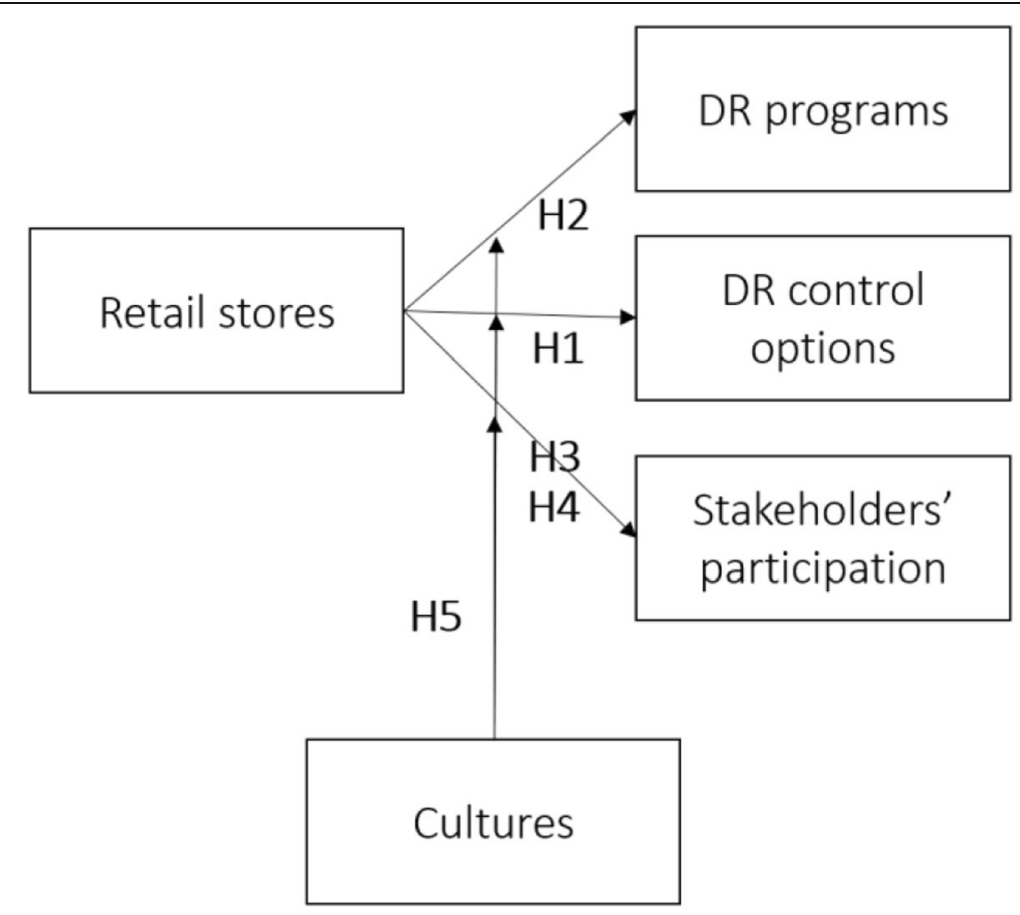

Fig. 1 Overview of the conceptual model

\section{Methodology}

To investigate the demand response adoption of retail stores with the aspects of DR control preferences, customer engagement, and cross-national differences, this paper was targeted to survey altogether 200 managers of retail stores, 100 in Denmark (Fyn and Jutland) and 100 in the Philippines (in Manila, the capital). The questionnaire includes four parts based on the literature review and expert input as shown in Table 1. The respondents' profiles and organization size is presented in Table 2 and Table 3, respectively. To ensure content validity, the measures used in this study were adapted from established scales used in previous studies. For instance, a 5-point Likert scale was used for the part of motivation, barriers, and concerns, and the measures for this part were adapted from the studies by (Li et al., 2017) on the application of households' energy flexibility. With regard to the selection of the control strategies and stakeholders

Table 1 questionnaire content

\begin{tabular}{ll}
\hline Questionnaire section & Contents \\
\hline Background & $\cdot$ Number of employees \\
& $\cdot$ Number of stores \\
Control Strategies & $\cdot$ Store type \\
Motivation, barriers and concerns & $\cdot$ Preferences for control options \\
& $\cdot$ Concerns regarding control options \\
& $\cdot$ Financial aspects \\
Stakeholders' involvement & $\cdot$ Technological aspects \\
& $\cdot$ - Legaliness aspects \\
& $\cdot$ Employees and floor staffs \\
& $\cdot$ Customers \\
\hline
\end{tabular}


Table 2 Respondents' location and organizational type

\begin{tabular}{lccc}
\hline & Total & \multicolumn{2}{l}{ Organizational type } \\
\cline { 3 - 4 } & respondents & Domestic & International \\
\hline Denmark & 51 & 39 & 12 \\
The Philippines & 36 & 36 & 0 \\
\hline
\end{tabular}

surveyed, this paper was guided by the literature on energy flexibility in retail stores and commercial buildings (e.g. (Lamprinos et al., 2016) (Hutchinson, 2012)).

The data collection in both Denmark and the Philippines was conducted in 2017. Of these, 113 refused to participate due to the lack of interest or knowledge, resulting in a sample with a $43.5 \%$ response rate. Among the 87 surveyed managers, 51 were from Denmark and 36 from the Philippines. The surveyed managers were either store managers or store managers that were in charge of energy management in their stores.

All surveys were conducted by face to face visits describing the survey and explanation of survey questions. It reduced the barriers for participants to answer the questions regarding the concept of a smart grid, energy flexibility and control options that might not be familiar to some store managers. The energy-related knowledge and terms are popularly discussed in Denmark, but not so popular in the Philippines. Also, to reduce the practical constraints, e.g. travel and participants' willingness (e.g. time) to answer the survey, Fyn and Jutland in Denmark, and the capital- Manila in the Philippines were chosen to collect the survey.

The official languages of the Philippines are English and Filipino. The questionnaire is designed in English for the Philippines, and the data collection was conducted by a native Filipino, and she spoke either English or Filipino based on the managers' familiar languages locally. The questionnaire was translated into Danish for the data collection in Denmark and the data collection was conducted by native Danish researchers. The translation was checked with three native Danish researchers in the energy field. The questionnaire was designed and conducted by eight researchers with different knowledge levels of energy flexibility in buildings. Each questionnaire was collected by computer-assisted face-to-face interviewing that researchers explained each question and filled the answers with surveyed respondents.

The descriptive statistics were performed to uncover retail stores' preferences and concerns about DR control options, DR activities, and stakeholders' involvement. The data analysis was conducted with the statistical analysis software SPSS to analyze the cross-national differences and similarities, and retail stores' concerns towards DR options. The surveyed results are presented and discussed in section IV.

Table 3 Size of retail stores

\begin{tabular}{llll}
\hline Number of employees & Total percentage \% & In Denmark \% & In the Philippines \% \\
\hline$<49$ & 48.3 & 47.1 & 50 \\
$50-99$ & 6.9 & 7.8 & 5.6 \\
$100-499$ & 17.2 & 13.7 & 22.2 \\
$500-999$ & 5.8 & 5.9 & 5.5 \\
1000 or more & 21.8 & 25.5 & 16.7 \\
\hline
\end{tabular}




\section{Results}

\section{Retail stores have concerns toward different DR control options}

From the store managers' point of view, there are three energy control options for providing energy flexibility to the grid:

- Manual control - buildings manually turn on/off equipment and change set points in reaction to high electricity price signals

- Utility control- allow utility companies to send signals that would control electricity-powered appliance in buildings

- Building automation - Introduce an automatic system in buildings that can respond automatically to grid signals

In Fig. 2, the survey result shows that $48.2 \%$ of store managers were willing to do manual control to react to electricity price signals, whereas only $19.8 \%$ and $25.6 \%$ were willing for utility control and building automation. The result corresponds to the current situation that store managers are more willing to participate in the implicate DR (e.g. peak/off-peak hours) compared to explicit DR (e.g. aggregation) (Ma et al., 2017b). Although aggregators and their business models are popularly discussed in the literature, the result shows that $39.5 \%$ of store managers are not willing to accept utility control compared to $30.2 \%$ unwillingness of building automation. Therefore, aggregators might consider control building energy via buildings' own automation with signals.

A Mann-Whitney $U$ test indicated a statistically significant difference in the preference of manual control between Denmark (mean 34.5) and Philippines (mean 55.6). The result shows that the surveyed store managers in Denmark preferred manual control significantly more often than those in the Philippines $(\mathrm{U}=433,5, p<.001$ ). Meanwhile, no statistically significant difference in preferences with utility controls or building automation between these two countries was observed.

Regarding store managers' concerns for DR control options, the survey result (Fig. 3) shows that the top four concerns for store managers are: 'indoor lighting', 'causing damages to equipment', 'interfering with business activities', and 'effective energy bill

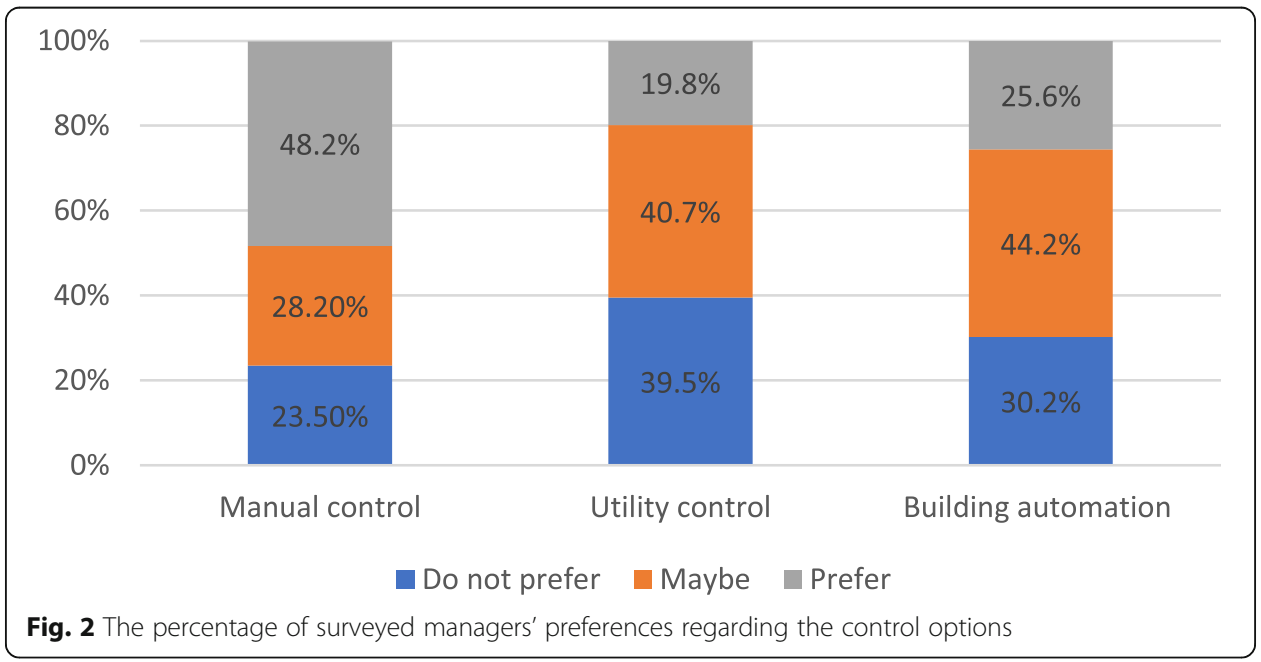




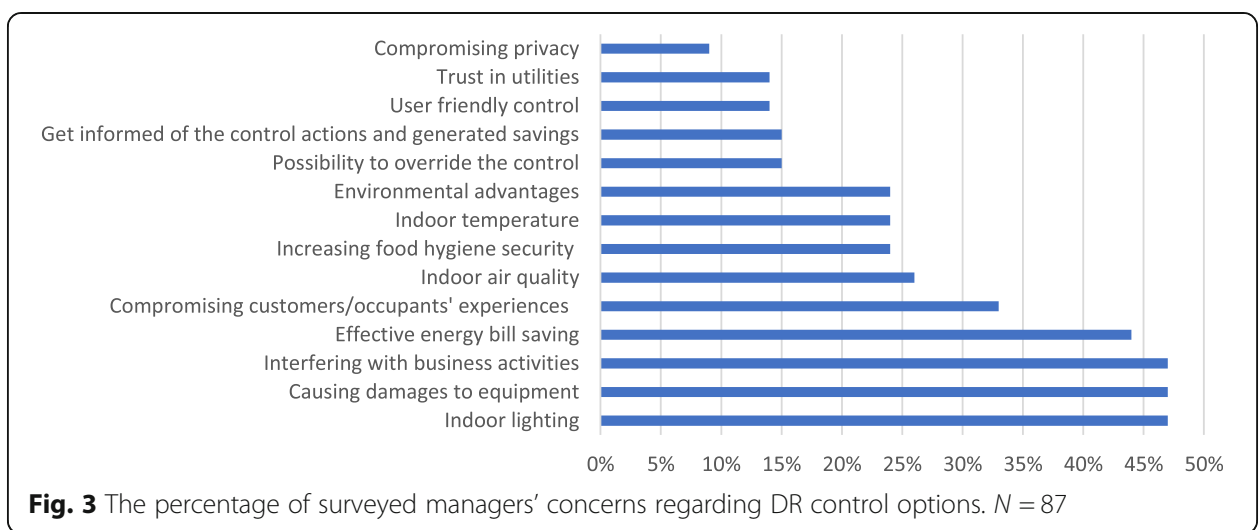

saving'. It means that the main concerns for store managers are maintaining normal building operations and financial benefits.

Figure 4 shows that the top 3 concerns for Danish store managers are: 'interfering with business activities', 'indoor light and compromising customers/occupants' experience'. Compared to Danish store managers, store managers in the Philippines concern more about 'causing damages to equipment', 'effective energy bill saving', 'indoor lighting' and 'interfering with business activities'. Surprisingly, store managers in both Denmark and the Philippines do not a concern so much about 'privacy' or 'user-friendly control'.

A Chi-Square test shows that there are four concerns that influence surveyed managers' option of DR manual control: equipment damage $\left(\chi^{2}(2)=14.175, p<\right.$ $0.001)$, energy bill $\left(x^{2}(2)=10.29, p<0.01\right)$, indoor lighting $\left(\chi^{2}(2)=8.033, p<0.05\right)$ and indoor temperature $\left(\mathrm{x}^{2}(2)=7.391, \mathrm{p}<0.05\right)$. The result shows that only indoor lighting $\left(\chi^{2}(2)=10.181, p<0.01\right)$ influences the option of DR utility control. Meanwhile, 'possibility to override the control' $\left(x^{2}(2)=7.4, p<0.05\right)$ has a significant influence on the option of building automation.

\section{Retail stores' DR program participation is related to various influential factors}

In the questionnaire, 17 factors that potentially influence store managers to participate in DR programs were categorized into financial, technological, business,

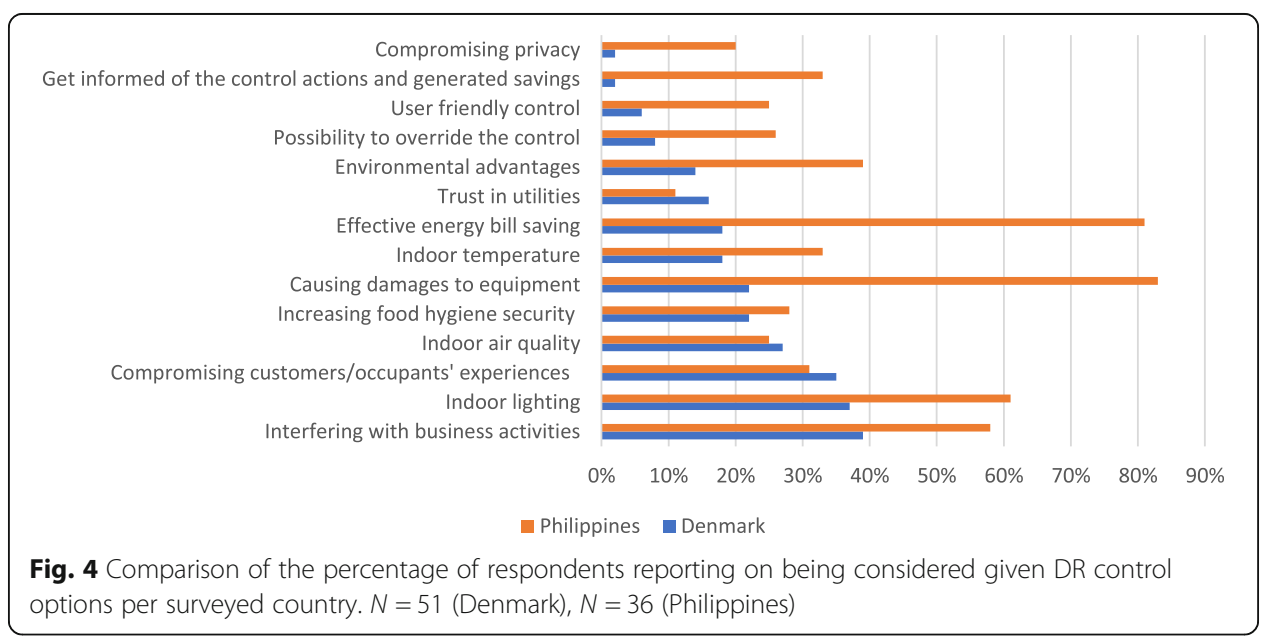




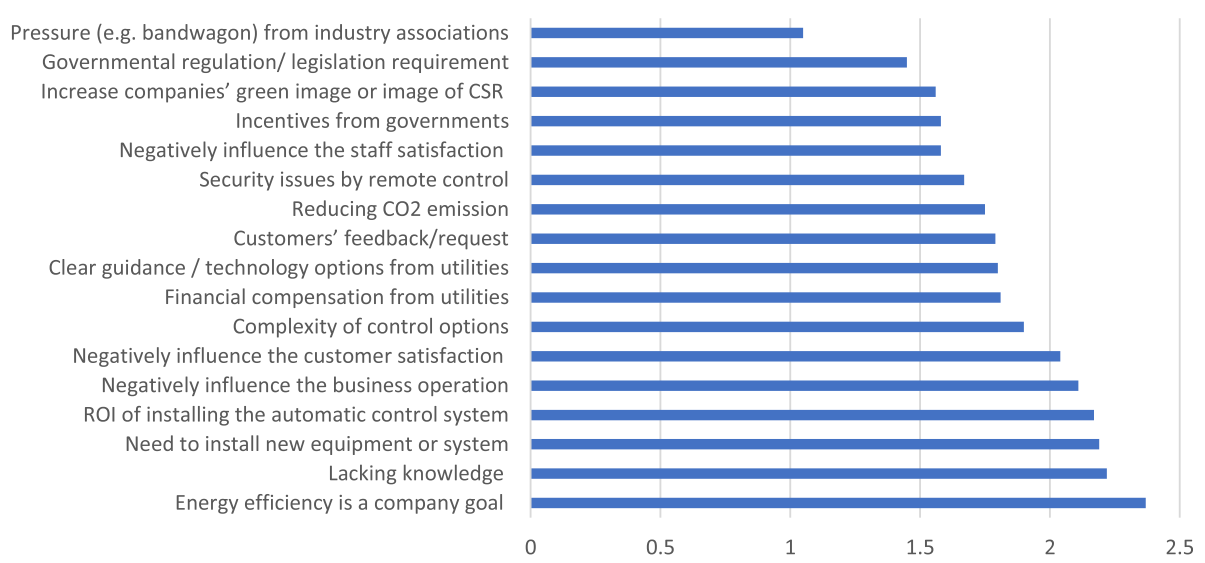

Fig. 5 Influential factors that surveyed managers consider being important to DR program participation. $N=87$

legal and environment aspects. Figure 5 shows, the ranking of the influential factors that store managers consider to be important for the participation of DR programs. Among the influential factors, store managers concern more about the business aspects, legal and environmental aspects are the least important (summarized in Table 4).

In general, store managers in Denmark have more concerns about the surveyed factors compared to those in the Philippines (shown in Fig. 6). Compared to store managers in Denmark, store managers in the Philippines only significant concern about 'lacking knowledge' and 'negatively influence the business operations' for the DR program participation.

\section{Retail stores have preferences for employees' participation in DR activities}

Literature (Christina et al., 2014) shows that some of the DR activities affect staffs rather than customers, and staffs are not actively involved in the DR activities. The surveyed result (Fig. 7) shows that the majority of store managers think employees should be informed regarding DR activities, but they do not think employees should be involved in either the DR strategies or be rewarded for their involvement. Meanwhile, the survey result (shown in Fig. 8) shows, 51\% of store managers in Denmark think that employees should involve in the DR strategies, and only $5.6 \%$ of store managers in the Philippines believe that employees should involve.

Of the surveyed store managers, $78.6 \%$ believe that employees cannot tolerate the frequent indoor comfort changes by dynamic control. Yet, $97.7 \%$ of the store managers do

Table 4 Top Influential factors and the correspondent aspects

\begin{tabular}{ll}
\hline Aspects & Top influential factors \\
\hline Business & - Energy efficiency is a company goal \\
& - Dynamic control can negatively influence the business operation \\
& - Dynamic control can negatively influence customer satisfaction (e.g. comfort) \\
Technology & - Need to install new equipment or system \\
Financial & - The company is Lacking knowledge \\
\hline
\end{tabular}




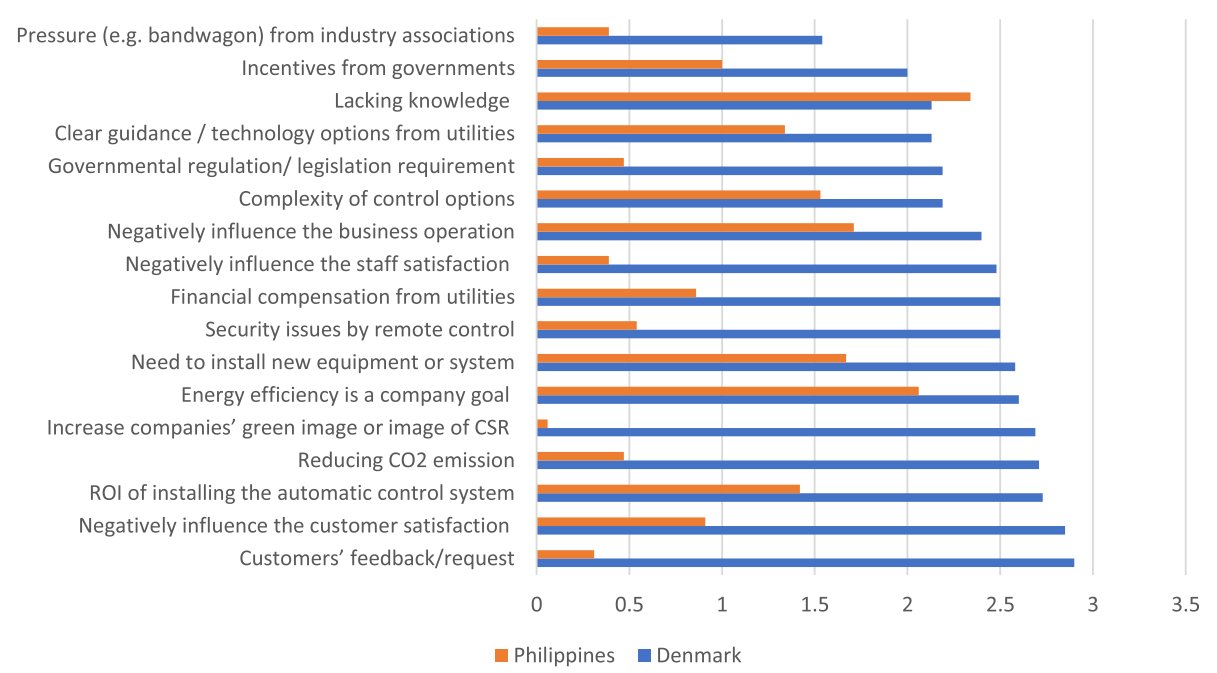

Fig. 6 The comparison of influential factors that surveyed managers consider to be important to DR program participation $N=51$ (Denmark), $N=36$ (Philippines)

not think employees should get compensation to reduce their dissatisfaction (Fig. 9). In Denmark, $62.7 \%$ of the surveyed store managers believe that dynamic control will decrease employees' satisfaction, whereas only $13.9 \%$ of store managers in the Philippines believe the same (Fig. 10). On the contrary, more store managers in the Philippines (90.9\%) believe employees cannot tolerate the frequent indoor comfort changes through dynamic control compared to Denmark (70.6\%).

\section{Retail stores have preferences of customers' participation in DR activities}

Of all surveyed store managers, $86.2 \%$ think that it is necessary to inform customers about DR activities in stores (Fig. 11). However, 74.7\% of them do not believe that advertisement of store energy program can increase customers' acceptance of frequent indoor comfort changes, and 77\% of them believe that customers' in-store engagement/ experience of the energy program cannot increase customers' acceptance of frequent indoor comfort change. Compared to the Philippines, store managers in Denmark consider more advertisement and in-store engagement can increase customers' acceptance of indoor comfort change (shown in Fig. 12).

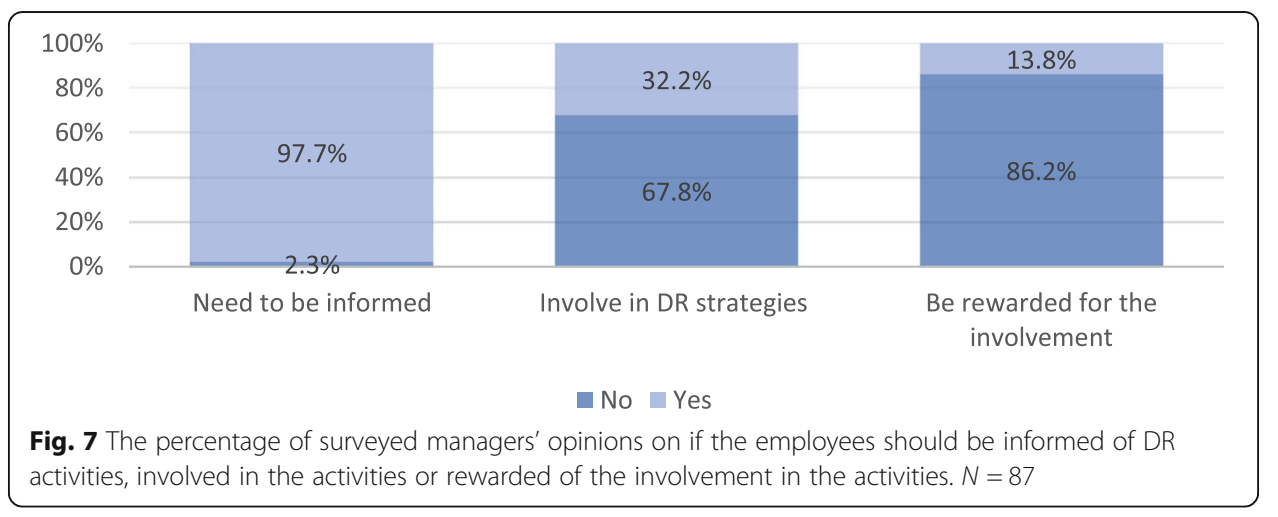



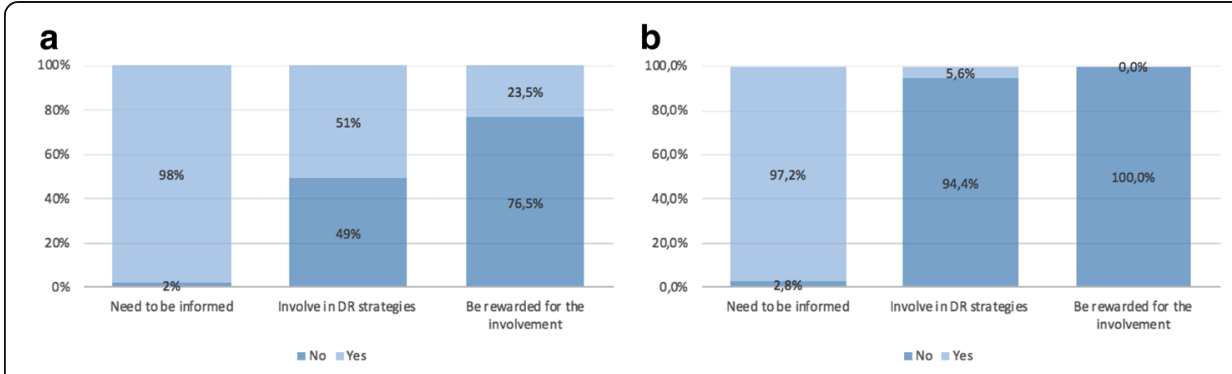

Fig. 8 a the percentage of surveyed Danish managers' opinions on employees' participation in the DR program. $N=51$. Figure $\mathbf{b}$ the percentage surveyed Philippines managers' opinions on employees' participation in the DR program. $N=36$

\section{Discussion}

The result shows that retail stores prefer manual energy control compared to utility control or building automation. The main reasons are due to the potential interference of retail stores' business activities caused by the energy control. Retail stores' concerns related to the manual control preferences are equipment damage, saving bills, indoor temperature, and indoor lighting.

There are six factors that retail stores believe important to DR participation. They are company goal, lacking related knowledge, new equipment installation, ROI, business operation and customer satisfaction. However, legal and environmental factors are not believed by the retail stores as important factors to DR participation.

Regarding stakeholder engagement, the result shows, retail stores believe that their employees and customers should be informed regarding stores' DR participation, due to the potential interference of employees' working environment and customers' shopping experience. However, retail stores prefer not to include either their employees or customers in the DR strategies or activities. Meanwhile, retail stores have mainly received and expect to receive more information regarding energy bill reduction or energy-saving from the utilities. This result shows, the focus of retail stores is still energy efficiency, not energy flexibility. The financial benefit is the main reason.

This paper finds out that there are significant differences regarding the energy control preferences and concerns between retail stores in Denmark and the

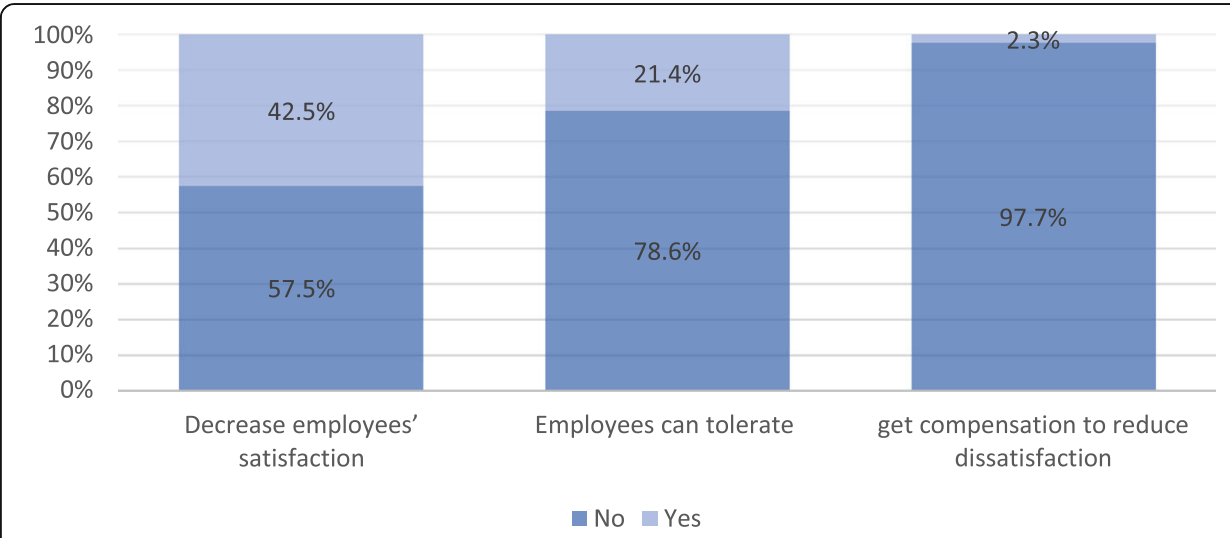

Fig. 9 The percentage of surveyed managers' beliefs on employees' satisfaction due to dynamic control. $N=87$ 


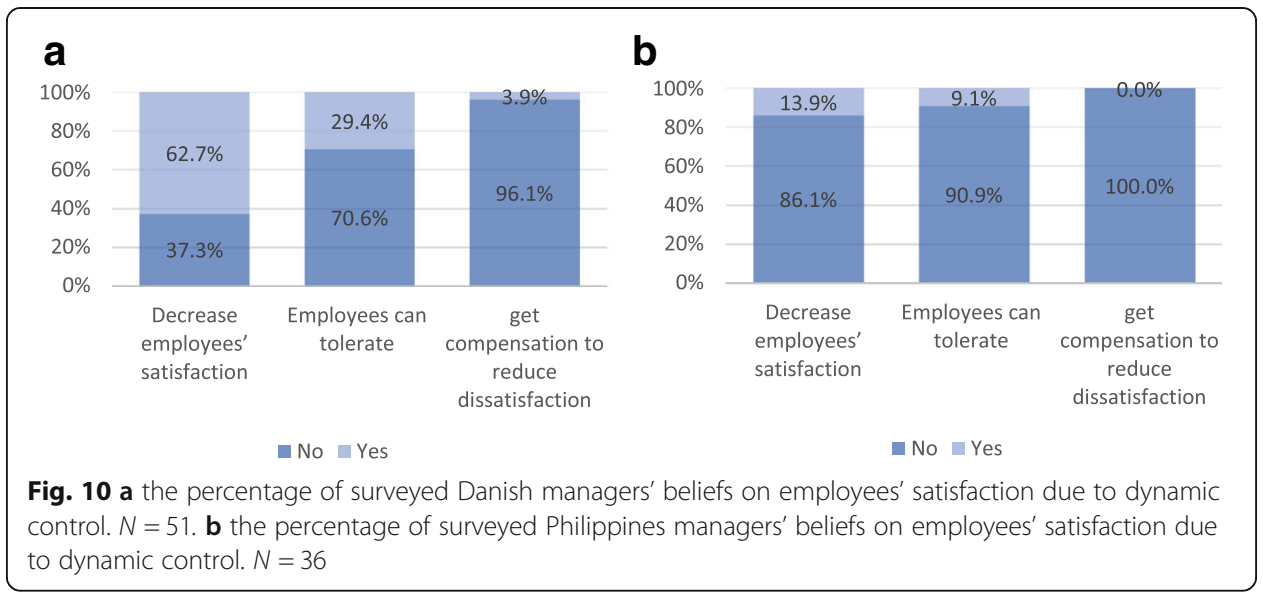

Philippines, but no significant difference regarding stakeholder engagement. The differences are mainly due to the different energy supply situations across the two countries. For instance, there is increasing energy demand in the Philippines that still cannot be fulfilled. Therefore, the urgent need in the Philippines is not creating the energy flexibility market but increasing energy production. Meanwhile, the insignificant difference regarding stakeholder engagement presents the similarity of the same sector across countries.

Although the literature has discussed the potentials and benefits of energy flexibility in commercial buildings from theoretical and technical perspectives, the investigation of retail stores' DR participation in this paper shows, retail stores in either Denmark or the Philippines have not been ready to participate in explicit DR programs. Literature shows that DR control options are mainly influenced by retail stores' capacity for providing energy flexibility. The result of this paper reveals that retail stores concern more about business operations and financial benefits compared to technic potentials or constraints.

\section{Conclusions}

This paper investigates the retail stores' adoption for participation in DR programs with three aspects: energy control preferences, stakeholder engagement, and crossnational differences. By uncovering retail stores' concerns and willingness towards DR participation, this paper contributes to developing potential business models

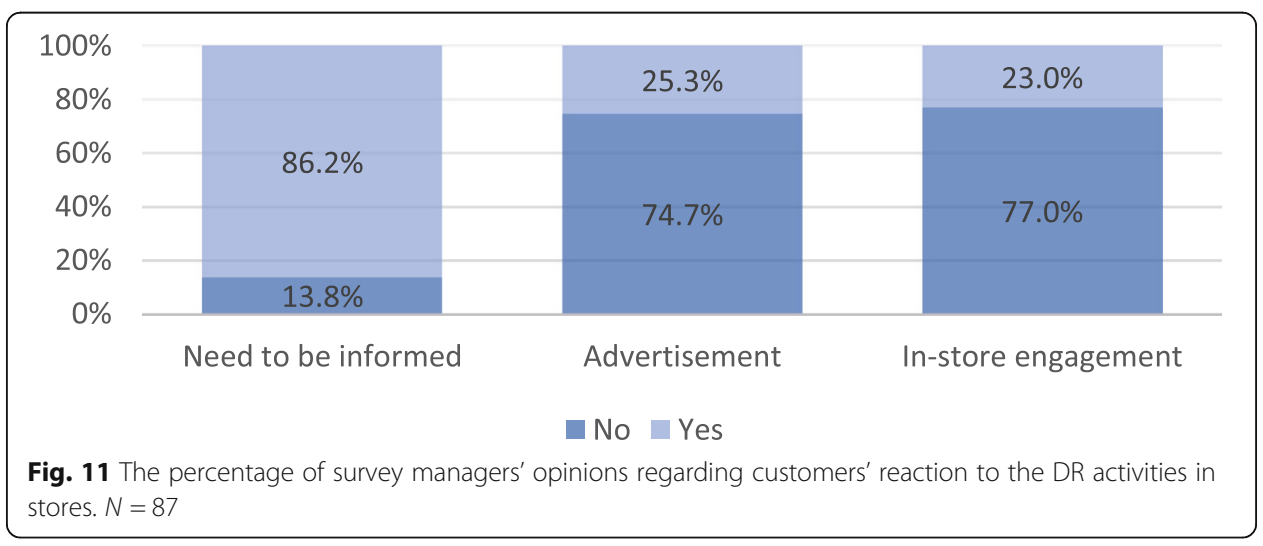




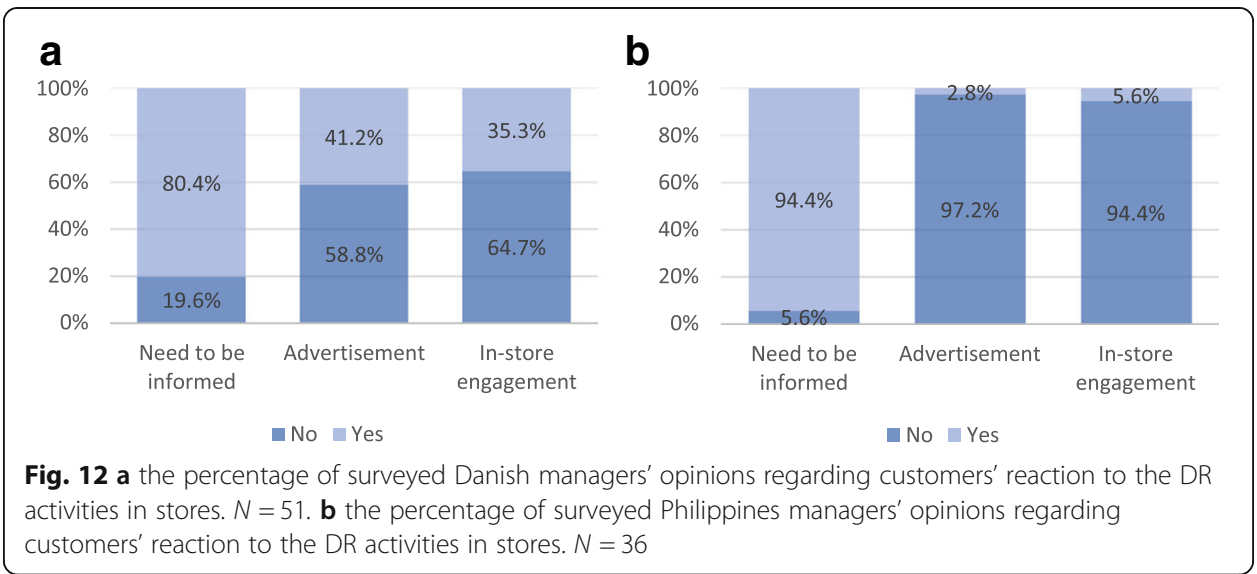

for retail stores to participate the DR programs based on their preferences and constraints (shown in Fig. 13).

The research results not only fill the theatrical gap of retail stores' DR participation but also provide managerial knowledge to stakeholders in the DR market, e.g. aggregators and utilities. For instance, aggregators are interested in trading the distributed loads from the consumers' flexibility, and commercial consumers (e.g. retail stores) have large flexibility potentials due to their energy profiles. However, incentives for consumers to provide their flexibility are important but not clear to the aggregators. Therefore, this paper's research results can help aggregators to understand retail stores' concerns and preferences towards the DR program participation.

DR is believed as a collective innovation in the smart grid. However, the result of this paper shows that retail stores prefer to not directly engage other stakeholders in DR activities, although it is necessary to consider other stakeholders' opinions and preferences. Therefore, future research is recommended to focus on different stakeholders that provide different angles to retail stores' DR participation.

Meanwhile, a survey only cannot cover all aspect for a cross-national comparative analysis. Therefore, to present an overall understanding of the stakeholders' roles and engagement, the follow-up qualitative interviews are recommended to be conducted, not only with retail store managers but also with other stakeholders, e.g. utilities and authorities.

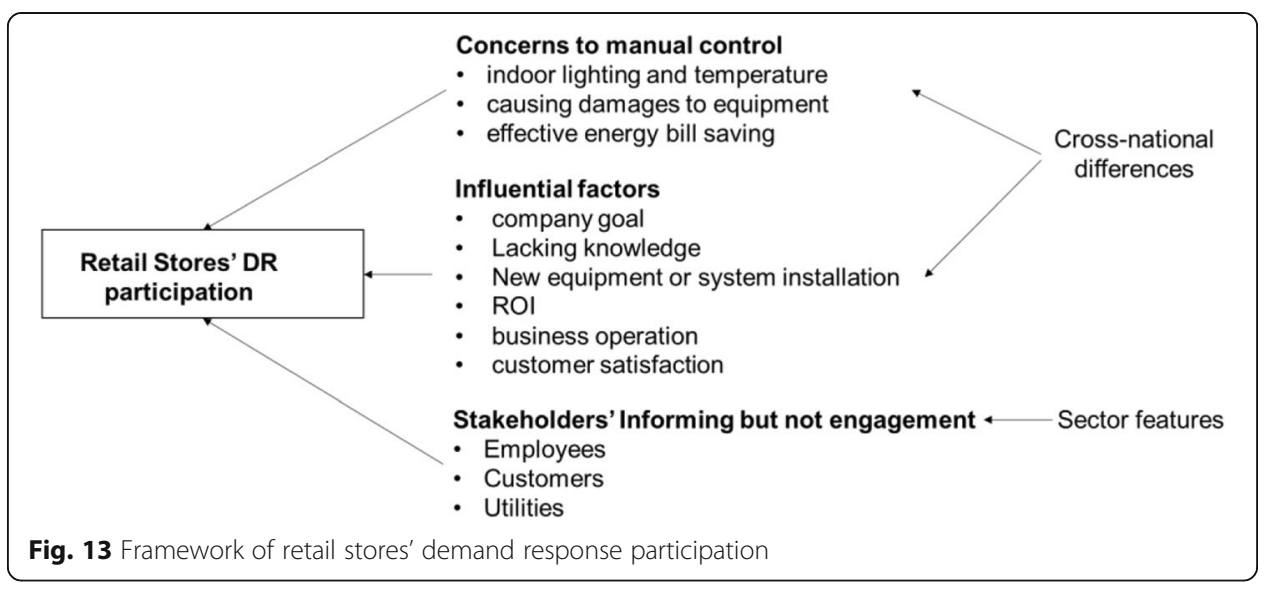




\section{Abbreviations}

BAS: Building Automation Systems; CSR: Corporate Social Responsibility; DOE: Department of Energy; DR: Demand Response; DSOs: Distribution System Operators; GHG: Greenhouse gas; HVAC: Heating, Ventilation, and Air Conditioning; NGO: Non-Governmental Organization; ROI: Return on Investment; TSOs: Transmission System Operators; VFDs: Variable Frequency Drives

\section{Acknowledgments}

Morten Ratzer Pedersen conducted the data collection in Denmark, and Joy Billanes conducted the data collection in the Philippines.

The Authors guarantee that the contribution to the work has not been previously published elsewhere, only the section of the Research Background is based on a previous work that is published as a conference paper (Ma et al., 2017c), and has been restructured.

\section{Authors' contributions}

ZM carried out the first draft of the paper, KK participated in the data analysis design, and MBK participated in the questionnaire design and paper revision. All authors read and approved the final manuscript.

\section{Funding}

This work was part of the project- FlexReStore funded by ForskEL foundation, Denmark, and IEA Annex67 projectEnergy Flexible Building.

\section{Availability of data and materials}

The datasets used and analyzed during the current study are available from the corresponding author on reasonable request.

\section{Ethics approval}

Not applicable

\section{Consent for publication}

Not applicable.

\section{Competing interests}

The authors declare that they have no competing interests.

\section{Author details}

${ }^{1}$ SDU Center for Health Informatics and Technology, University of Southern Denmark, Odense, Denmark. ${ }^{2}$ SDU Software Engineering, University of Southern Denmark, Odense, Denmark. ${ }^{3}$ SDU Center for Energy Informatics, University of Southern Denmark, Odense, Denmark.

Received: 9 May 2019 Accepted: 30 July 2019

Published online: 22 August 2019

\section{References}

Carr H (2015) A custom approach for improved utility incentives. Electric Perspectives, Article 40(4):42-45

Christina S, Dainty A, Daniels K, Waterson P (2014) How organisational behaviour and attitudes can impact building energy use in the UK retail environment: a theoretical framework. Archit Eng Des Manag 10(1-2):164-179

Connell NO, Madsen H, Pinson P, Malley MO, Green T (2014) Regulating power from supermarket refrigeration. In: IEEE PES Innovative Smart Grid Technologies, Europe, pp 1-6

Council of the European Union (2011) Framework agreement on partnership and cooperation between the European Union and its member states, of the one part, and the Republic of the Philippines, of the other part. European Union, Brussels Available: https:/eeas.europa.eu/sites/eeas/files/eu_philippines_pca_20120712.pdf

Danish Energy Association (2013) Gennemsnitlige månedlige el-forsyningspligtpriser for forbrugere og virksomheder i Danmark. Danish Energy Association (Dansk Energi), Frederiksberg

Department of Energy (2016) 2015 Philippines Power Statistics. DOE, Republic of the Philippines Available: https://www.doe gov.ph/sites/default/files/pdf/energy_statistics/power_statistics_2015_summary.pdf

Ea Energianalyse, "Kortlægning af potentialet for fleksibelt elforbrug i industri, handel og service," 2011, Available: http://www. ea-energianalyse.dk/reports/1128_kortlaegning_af_potentialet_for_fleksibelt_elforbrug_i_industri.pdf

Ea Energianalyse, "Energibesparelser og fleksibelt elforbrug- Potentialevurdering til Energi på tværs," 2015, Available: http:// www.ea-energianalyse.dk/reports/1525/1525_potentialenotat_energibesparelser_fleksibelt_elforbrug.pdf

EnergiNet (2017) Electricity Security of Supply Report 2017. Energinet.dk, Vejle, Dnemark Available: https://en.energinet.dk/ About-our-reports/Reports/Security-of-Electricity-Supply-Report-2017

Energinet.dk, "Smart Grid i Danmark," 2010, Available: https:/www.teknologisk.dk/_/media/43656_anmd-Smart_Grid_i_ Danmark_Rapport.pdf

Energinet.dk, "Smart Grid in Denmark 2.0- Implementation of three key recomendations form the Smart Grid Network," 2011, Available: http://energinet.dk/SiteCollectionDocuments/Engelske\%20dokumenter/Forskning/Smart\%20Grid\%20in\%2 ODenmark\%202.0.pdf

Energinet.dk, "Delrapport Arbejdsgruppe 24 Roadmap for Smart Grid i Danmark med særlig vægt på netselskabernes rolle," 2012, Available: https://docplayer.dk/2307025-Delrapport-arbejdsgruppe-24-roadmap-for-smart-grid-i-danmark-medsaerlig-vaegt-paa-netselskabernes-rolle.html

European Environment Agency (EEA), "Achieving energy efficiency through behaviour change: what does it take?," 2013, Available: http://www.eea.europa.eu/publications/achieving-energy-efficiency-through-behaviour 
Eurostat, "Electricity prices for household consumers - bi-annual data (from 2007 onwards)," Eurostat, Ed., ed, 2018

D. Gerdeman, "designed to sell," Contract, Article vol. 49, no. 3, pp. 78-79, 2007

I. Gonzales. (2013). 16-M Pinoys do not have access to electricity - study. Available: https://www.philstar.com/business/2 013/11/25/1260424/16-m-pinoys-do-not-have-access-electricity-study

V. C. Gungor et al., "Smart grid technologies: communication technologies and standards," Industrial Informatics, IEEE Transactions on, vol. 7, no. 4, pp. 529-539, 2011

Hao H, Middelkoop T, Barooah P, Meyn S (2012) How demand response from commercial buildings will provide the regulation needs of the grid. In: 2012 50th annual Allerton conference on communication, control, and computing (Allerton), pp 1908-1913

Hayter PATSJ A case study of the energy design process used for a retail application. In: Presented at the American solar energy society (ASES) conference, Madison, Wisconsin, 2000 Available: http://citeseerx.ist.psu.edu/viewdoc/ download?doi=10.1.1.476.3826\&rep=rep $1 \&$ type $=$ pdf

Heiskanen E, Matschoss K (2011) Exploring emerging customer needs for smart grid applications. In: In Innovative Smart Grid Technologies (ISGT Europe), 2011 2nd IEEE PES International Conference and Exhibition on, pp 1-7

M. Huber, D. Dimkova, and T. Hamacher, "Integration of wind and solar power in Europe: assessment of flexibility requirements," Energy, vol. 69, pp. 236-246, 2014.

Hutchinson EM (2012) New retail store model for delivering energy efficiency in Massachusetts. MSc, Massachusetts Institute of Technology. Dept. of Urban Studies and Planning, Massachusetts Institute of Technology, Massachusetts

Iwaro J, Mwasha A (2010) A review of building energy regulation and policy for energy conservation in developing countries. Energy Policy 38(12):7744-7755

Jianli P, Jain R, Paul S (2014) A survey of energy efficiency in buildings and microgrids using networking technologies. IEEE Commun Surv Tutorials 16(3):1709-1731

JRC Science Hub, "Addressing flexibility in energy system models," 2015, Available: https://setis.ec.europa.eu/sites/default/files/ reports/Addressing-flexibility-in-energy-system-models.pdf

Kolokotroni M, Tassou SA, Gowreesunker BL (2015) Energy aspects and ventilation of food retail buildings. In: Advances in Building Energy Research, vol. 9, no. 1, pp. 1-19

Lamprinos I, Hatziargyriou ND, Kokos I, Dimeas AD (2016) Making demand response a reality in Europe: policy, regulations, and deployment status. IEEE Commun Mag 54(12):108-113

Leal EMV (2000) Energy impact of ventilation in buildings. In: da Air Inviltration and Ventilation Centre Conference, AIVC2000, Haia, Holanda

Li R, Dane G, Finck C, Zeiler W (2017) Are building users prepared for energy flexible buildings?-a large-scale survey in the Netherlands. Appl Energy 203:623-634

Ma BNJZ (2016) Energy flexibility of the commercial greenhouse growers: the potential and benefits of participating in the electricity market. In: IEEE international conference on sustainable energy technologies (ICSET 2016). IEEE, Hanoi

Ma Z, Asmussen A, Jørgensen B (2018a) Industrial consumers' smart grid adoption: influential factors and participation phases. Energies 11(1):182

Ma Z, Billanes J, Jørgensen B (2017b) Aggregation potentials for buildings_-business models of demand response and virtual power plants. Energies 10(10):1646

Ma Z, Billanes JD, Jørgensen BN (2016b) The island smart energy system and market. In: 2016 IEEE International Conference on Power and Energy (PECon 2016), Melaka

Ma Z, Dalmacio Billanes J, Kjærgaard MB, Jørgensen BN (2017a) Energy flexibility in retail buildings: from a business ecosystem perspective. In: 2017 14th International Conference on the European Energy Market (EEM), Dresden, pp 1-6. https://doi.org/10.1109/EEM.2017.7981962

Ma Z, Billanes JD, Kjærgaard MB, Jørgensen BN (2017c) Energy flexibility in retail buildings: from a business ecosystem perspective. In: 2017 14th International Conference on the European Energy Market (EEM). IEEE, Dresden, pp 1-6

Ma Z, Broe M, Fischer A, Sørensen TB, Frederiksen MV, Jøergensen BN (2019) Ecosystem thinking: creating microgrid solutions for reliable power supply in India's power system. presented at the the IEEE global power, energy and communication conference 2019 (IEEE GPECOM 2019), Cappadocia

Ma Z, Jørgensen BN, Billanes JD (2016a) Smart energy in the Philippines. Center for Energy Informatics, University of Southern Denmark, Odense Available: http://findresearcher.sdu.dk/portal/files/141095725/CFEl_Report_Smart_Energy_in_ Philippines.pdf

Ma Z et al (2018b) Peer-to-peer trading solution for microgrids in Kenya. In: 2018 IEEE PES/IAS PowerAfrica conference - river Club, Cape Town, South Africa. IEEE, Cape Town

Mandatova P, Lorenz G (2013) EURELECTRIC paper.Network tariff structure for a smart energy system

Mehrara M (2007) Energy consumption and economic growth: the case of oil exporting countries. Energy Policy 35(5): 2939-2945

Mills MK (1984) Energy issues and the retail industry: public policy/marketing implications. J Public Policy Mark 3:167-183

Ochieng EG, Jones N, Price ADF, Ruan X, Egbu CO, Zuofa T (2014) Integration of energy efficient technologies in UK supermarkets. Energy Policy 67:388-393

Robert JS, King P, Poppert W The 2001 Supermarket Panel energy management Study, p 47 Available: http://ageconsearch. umn.edu/bitstream/14332/1/tr03-03.pdf. Accessed on: 13 April, 2016

Samad T, Kiliccote S Smart grid technologies and applications for the industrial sector. Comput Chem Eng 47(0):76-84 12/20/ 2012

Sebastian S, Margaret V (2016) Application of demand response programs for residential loads to minimize energy cost. In: 2016 International Conference on Circuit, Power and Computing Technologies (ICCPCT), pp 1-4

Tassou SA, Lewis JS, Ge YT, Hadawey A, Chaer I (2010) A review of emerging technologies for food refrigeration applications. Appl Therm Eng 30(4):263-276

Vukojevic A, Milošević B (2010) Utilities of future. In: Sustainable Energy Technologies (ICSET), 2010 IEEE International Conference on, Kandy, sir Lanka, pp 1-6 
Yang Z, Wang L (2016) Demand response management for multiple utility companies and multi-type users in smart grid. In: 2016 35th Chinese control conference (CCC), pp 10051-10055

Zaatari M, Novoselac A, Siegel J (2016) Impact of ventilation and filtration strategies on energy consumption and exposures in retail stores. Build Environ 100:186-196

Zheng M, Prljaca Z, Jørgensen BN (2016) The international electricity market infrastructure-insight from the nordic electricity market. In: 2016 13th international conference on the European energy market (EEM), pp 1-5

\section{Publisher's Note}

Springer Nature remains neutral with regard to jurisdictional claims in published maps and institutional affiliations.

Submit your manuscript to a SpringerOpen ${ }^{\odot}$ journal and benefit from:

- Convenient online submission

Rigorous peer review

- Open access: articles freely available online

- High visibility within the field

- Retaining the copyright to your article

Submit your next manuscript at $\boldsymbol{\nabla}$ springeropen.com 